Milanka Điporovic-Momčilović, Mlađan Popović*, Jasmina Popović, Ivana Gavrilović-Grmuša, Fadhil Hamid, Ahmad Hakky Mohamad

University of Belgrade, Faculty of Forestry, Belgrade, Serbia
Scientific paper

ISSN 0351-9465, E-ISSN 2466-2585

UDC:504.75:725.21/.26(497.11)

doi:10.5937/zasmat1804484D

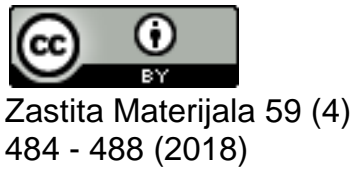

\title{
Quality of the particleboards on serbian market in regard to the formaldehyde emission
}

\begin{abstract}
The formaldehyde potential of particleboards imported on Serbian market was evaluated in this research. The sampling and testing of particleboards were conducted in two discrete periods: first was during 2011 and the second was in the period of 2015-2016. For both periods, the samples of raw particleboards originated from three different producers. The perforator method (EN 120) was used to test the formaldehyde content in the particleboard samples. In general, the results have showed that the majority of the samples belong to the E1 class of particleboards. In addition, $19 \%$ of the particleboards sampled in 2011 and $31 \%$ of the boards sampled in 2015-2016 were found to have formaldehyde content below $50 \%$ of $E 1$ class requirements.
\end{abstract}

Keywords: particleboards, formaldehyde, emission class, perforator.

\section{INTRODUCTION}

The exposure to formaldehyde can cause various symptoms and harmful effects on the human health. The increased concentration of formaldehyde in the surrounding air can cause the irritation of eyes, nose, throat and skin, which in more severe cases can lead to asthma and allergic reactions [1]. The World Health Organization (WHO) have classified the formaldehyde as the probable carcinogen to human (Group 2A), and in the 2004 the International Agency for Research on Cancer (IARC) has recommend the reclassification of formaldehyde as carcinogen to humans (Group 1) [2]. The wood-based panel products produced with adhesives that contain the formaldehyde are indentified as the sources of formaldehyde in interior atmosphere. As a cross-linking agent for organic materials, the formaldehyde readily reacts with phenol, urea and melamine monomers, thus creating the family of formaldehyde based adhesives used in the industry of wood based panels such as the particleboards, MDF, hardboards and plywood [3].

\footnotetext{
${ }^{*}$ Corresponding author: Mladjan Popovic

E-mail: mladjan.popovic@sfb.bg.ac.rs

Paper received: 28. 06. 2018.

Paper accepted: 17. 07. 2018.

Paper is available on the website: www.idk.org.rs/journal
}

The urea-formaldehyde (UF) resin is the most common adhesive system still used today for the production of interior class of wood-based composite panels. In 2001 the UF adhesive alone has amounted for $80 \%$ of the 6 million tons of total adhesive consumption by the European producers of wood-based panels [4]. Except for its low price, the advantages of UF adhesive can be found in its relatively quick curing time in the hot press, transparent or white glue-line, good adhesive strength, while at the same time it incorporates the significant production experience [5]. Although it belongs to the group of thermo-reactive adhesives, the cured UF adhesive (in wood-based panels) is susceptible to the hydrolysis of its weakly bound formaldehyde from $\mathrm{N}$-methylol groups, acetals and hemiacetals, but also from methylene-ether linkages at high relative humidity, which altogether increase the content of emitable formaldehyde and create the permanent pool for the subsequent formaldehyde emission [6]. The mechanism of formaldehyde emission depends on the rate of its formation in the material, transport through the material and its transfer from the material into the atmosphere [7]. Besides the various processing parameters, the formaldehyde to urea ratio $(F / U)$ is one of the initial factors that influence the formaldehyde emission from wood-based panels. Hence, lowering the $\mathrm{F} / \mathrm{U}$ ratio enables the production of boards with lower formaldehyde emission [8]. The rate of the subsequent formaldehyde emission from wood-based panels 
also depends on the ambient conditions, i.e. the temperature and relative humidity. It was found that the increased temperature and/or humidity of surrounding air significantly increase the formaldehyde emission rate from the boards [9-12].

In 2010, the Republic of Serbia has accepted the European standards (EN) regarding the formaldehyde emission limits for the wood based panels, developed by the European Committee for Standardization (CEN). Standards such as, EN
312, EN 622-1 and EN 300 define the requirements for the particleboards, fiberboards and OSB panels, respectively; while the EN 13986 presents the harmonized standard that defines the emission limits for the wood based panels used in constructions (Table 1). Although many European countries still allow the production and distribution of E2 class of wood-based panels, the regulations in countries like Germany, Austria, Denmark and Sweden requires the compliance with E1 class [2].

Table 1. Formaldehyde classes for wood based panels according to the EN standards

Tabela 1. Klase formaldehida za ploče na bazi drveta prema EN standardima

\begin{tabular}{|c|c|c|c|}
\hline Formaldehyde class & Panel type / standard & $\begin{array}{c}\text { Formaldehyde Release } \\
\left(\mathrm{mg} / \mathrm{m}^{3} \text { air }\right)\end{array}$ & $\begin{array}{c}\text { Formaldehyde content } \\
\text { (mg/100g o.d. board) }\end{array}$ \\
\hline \multirow{4}{*}{ E1 class } & EN $13968^{a}$ & \multirow{4}{*}{$\leq 0,124$} & \multirow{4}{*}{$\leq 8$} \\
\hline & EN $622-1^{b}$ & & \\
\hline & EN $312^{c}$ & & \\
\hline & EN $300^{d}$ & & \\
\hline \multirow{4}{*}{ E2 class } & EN 13968 & \multirow{2}{*}{$>0,124$} & \multirow{2}{*}{$>8 \leq 30$} \\
\hline & EN 622-1 & & \\
\hline & EN 312 & \multirow{2}{*}{$>0,124 \leq 0,3$} & \multirow{2}{*}{$>8 \leq 20$} \\
\hline & EN 300 & & \\
\hline
\end{tabular}

${ }^{\mathrm{a}}$ Wood-based panels for use in construction - Characteristics, evaluation of conformity and marking, ${ }^{\mathrm{b}}$ Fibreboards Specifications - Part 1: General requirements, 'Particleboards - Specifications, ${ }^{\mathrm{d}}$ Oriented Strand Boards (OSB) Definitions, classification and specifications, ${ }^{\mathrm{e}}$ Relates to the unfaced wood based panels

This paper presents the results of the survey on the formaldehyde class of the particleboards distributed in the Serbian market. The survey was made during 2011 and again during 2015-2016, and included imported particleboards used for furniture production.

\section{MATERIALS AND METHODS}

The commercial particleboards were sampled from the distributors in Republic of Serbia. The samples originate from three different producers, and the sample series were designated accordingly as: "A", "B" and "C". Each sample series comprised of 5 to 7 particleboard samples selected randomly. All of the samples of particleboards belonged to the P2 class according to the EN 312, which relates to the boards for interior fitments (including furniture) for use in dry conditions. Thickness of the selected particleboard samples ranged from 16 to $25 \mathrm{~mm}$. The moisture content of the samples was determined after drying the test pieces to the constant mass at $103 \pm 2^{\circ} \mathrm{C}$ in the laboratory oven, as described in the EN 322.

The formaldehyde content of the particleboards was determined by the extraction method, the so called perforator method, according to the EN 120 standard [13] (replaced with EN ISO 12460-5 from 2015). During the extraction phase, the particleboard test samples (approx. $110 \mathrm{~g}$ ) were submerged into the boiling toluene for $2 \mathrm{~h}$, to allow the extraction of formaldehyde and its transfer into the distiled water. The blank test was also performed without the test samples. The acetylacetone method was used to prepare formaldehyde aqueous extracts for determination of formaldehyde. The absorbance of the solution was determined by the UV spectrophotometer (Evolution 300), at the wavwlenght of $412 \mathrm{~nm}$. Then, the perforator value was calculated according to the following equation:

$$
\begin{aligned}
& P_{v}=\frac{\left(A_{S}-A_{B}\right) \cdot f \cdot(100+H) \cdot V}{m} \\
& {[m g / 100 g \text { of oven-dry board] }}
\end{aligned}
$$

where: $\boldsymbol{A}_{\boldsymbol{S}}$ is the absorbance value of extracted formaldehyde solution; $\boldsymbol{A}_{\boldsymbol{B}}$ is the absorbance of blank test solution (blank test); $\boldsymbol{f}$ is the slope of the calibration curve $(\mathrm{mg} / \mathrm{ml}) ; \boldsymbol{H}$ is the mositure content of particleboard sample (\%); $\boldsymbol{V}$ is the volume of the volumetric flask (2000 $\mathrm{ml}$ ) and $\boldsymbol{m}$ is the total mass of the test pieces used in extraction (g).

Since the perforator value applies for the particleboards with the moisture content of $6.5 \%$, the results were multiplied with the correction factor for moisture content $(F)$ which is calculated by the following equation (EN 312):

$$
F=-0.133 H+1.86
$$


The standard formaldehyde solution was used to obtain the calibration curve, for each sample series. The concentration of standard solution was determined by iodometric titration. The calibration solutions were then prepared for the determination of absorbance using UV spectrophotometer.

The statistical analysis of the results between two sample series was performed by the ANOVA (single factor) method, with the level of confidence of $95 \%$.

\section{RESULTS AND DISCUSION}

In the 2011 survey the formaldehyde values were significantly higher for the particleboards originating from the producer B (Table 2 and 3 ). The formaldehyde content values for other two particleboard series (producer A and C) did not differ significantly. In the later survey of the 20152016 period, the formaldehyde values for all three producers were not statistically different at the confidence level of $95 \%$.

When comparing the two survey periods, only the particleboards series from the producer $B$ have showed the change in the formaldehyde content values, with the boards sampled in 2015-2016 period showed statistically significant lower results.

Table 2. Mean perforator values of the particleboards from different producers determined during the surveys in 2011 and 2015-2016

Tabela 2. Srednje vrednosti sadržaja formaldehida po perforator metodi za ploče iverice različitih proizvođača, određenih tokom perioda ispitivanja u 2011. godini i 2015-2016. godini.

\begin{tabular}{|c|c|c|c|c|}
\hline \multirow{2}{*}{ Producer } & \multicolumn{2}{|c|}{2011} & \multicolumn{2}{c|}{$2015-2016$} \\
\cline { 2 - 5 } & P & st. dev. & P & (mg/100g o.d. board $)^{*}$ \\
\hline A & 5.28 & 0.79 & 5.63 & 0.70 \\
\hline B & 7.55 & 1.50 & 5.26 & 1.57 \\
\hline C & 3.80 & 1.42 & 4.28 & 1.53 \\
\hline
\end{tabular}

*the individual results are calculated to the moisture content of $6.5 \%$.

The lowest values of formaldehyde content for individual particleboard samples were found for the producer C. These values were 2.3 and 3.2 $\mathrm{mg} / 100 \mathrm{~g}$ of oven dried board, in the 2011 and 2015-2016 surveys, respectively.

Table 3. Statistical comparison of the formaldehyde content values (ANOVA)

Tabela 3. Statističko upoređenje vrednosti sadržaja formaldehida (ANOVA)

\begin{tabular}{|c|c|c|c|c|c|c|c|}
\hline \multirow{2}{*}{ Between groups } & \multicolumn{2}{|c|}{2011} & \multicolumn{2}{c|}{$2015-16$} & \multirow{2}{*}{ Between groups } & \multicolumn{2}{c|}{$2011 / 2015-16$} \\
\cline { 2 - 5 } & P-value & F/Fcrit & P-value & F/Fcrit & & P-value & F/Fcrit \\
\hline A/B & 0.008348 & $2.161508^{*}$ & 0.638823 & 0.046088 & $\mathrm{~A}_{2011} / \mathrm{A}_{2015-16}$ & 0,505425 & 0,096114 \\
\hline $\mathrm{B} / \mathrm{C}$ & 0.004216 & $2.939176^{*}$ & 0.347209 & 0.187545 & $\mathrm{~B}_{2011} / \mathrm{B}_{2015-16}$ & 0,035805 & $1,188330^{*}$ \\
\hline $\mathrm{A} / \mathrm{C}$ & 0.063650 & 0.870296 & 0.106107 & 0.630131 & $\mathrm{C}_{2011} / \mathrm{C}_{2015-16}$ & 0,643895 & 0,041709 \\
\hline
\end{tabular}

*denotes a statistically significant difference at the confidence level of $95 \%$.

It was also interesting to find how boards comply with the formaldehyde classification according to European standards, as stated in the Table 1. Hence, the Figure 1 shows the proportion between the E1 and E2 classes of particleboards sampled from the Serbian market, and also the contribution of particleboards that comply with half of the E1 class limits, which is important for Eco labeling and Blue Angel classes of boards [14, 15].
In the 2011 survey, close to 1/5 of the sampled particleboards belonged to the E2 class, i.e. having the formaldehyde content higher than the $\mathrm{E} 1$ limit value ( $8 \mathrm{mg} / 100 \mathrm{~g}$ of oven dried board); while during the later survey (2015-2016) there were no particleboards of E2 class found in the scope of this research (tested particleboards originate from only three producers with highest ratio of imported quantities). It was also interesting to notice that the proportion of samples with half the E1 limit has slightly increased. 


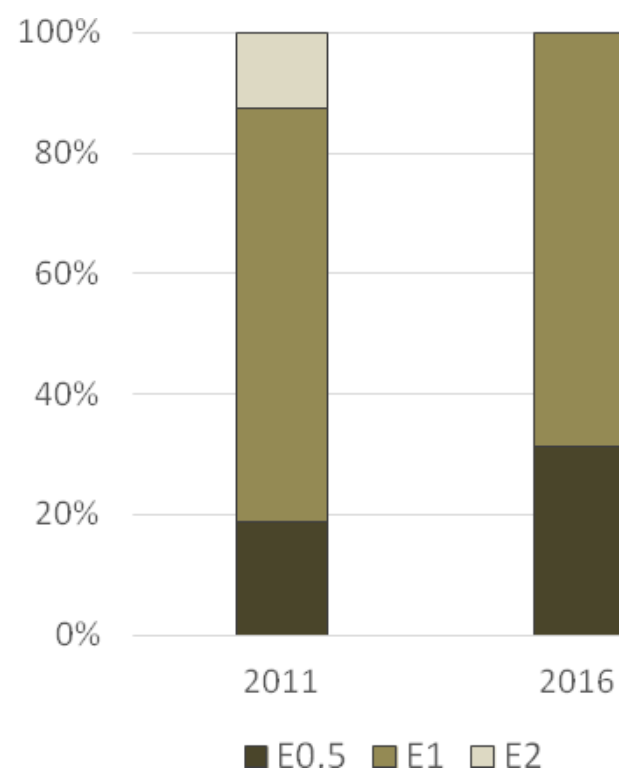

Figure 1. Proportion of the different formaldehyde classes of particleboards according to the survey made in 2011 and during 2015-2016 period in Serbia

Slika 1. Učešće ploča iverica različitih klasa formaldehida na osnovu preglednih ispitivanja tokom 2011. godine i 2015-2016. godine u Srbiji

Having in mind that, for the two survey periods, there were no significant differences in formaldehyde values for the particleboard samples originating from producers $\mathrm{A}$ and $\mathrm{C}$, and that there were only three different producers in the scope of this research, it is not certain if these indicators show the improvements of particleboard quality in terms of formaldehyde content. However, these data allow us to reasonably assume that the particleboards of $\mathrm{E} 1$ class are dominant on our domestic market, which is of the great importance, not only for the consumers of particleboards in Serbia, but also for the export on European market.

\section{CONCLUSIONS}

The the samples of commercial particleboards marketed in Serbia tested in this research were mainly E1 class of board. However, the survey made in 2011 found that $87 \%$ of the boards belong to the E1 class, while the rest was the E2 class. Yet, in the later survey, during 2015 and 2016, all the boards were found to belong to E1 class.

In addition, the proportion of the boards that have $50 \%$ of $E 1$ class has also increased from 19 $\%$ in 2011 to $31 \%$ in the later survey. This relatively low formaldehyde content in the boards is one of the conditions for these products to achieve EU Ecolabel mark.

There were significant differences in the results of formaldehyde tests in 2011 between the selected producers, however in 2015-2016 survey there were no such statistically significant differences at the confidence level of $95 \%$.

\section{Acknowledgments}

This paper was realized as a part of the project "Establishment of Wood Plantations Intended for Afforestation of Serbia" (TP 31041) financed by the Ministry of Education and Science of the Republic of Serbia within the framework of integrated and interdisciplinary research for the period 2011-2014.

\section{REFERENCES}

[1] D. A.Kaden, C.Mandin, G.D.Nielsen, P.Wolkoff, P. (2010) Formaldehyde. Chapter 3 in: WHO Guidelines for Indoor Air Quality: Selected Pollutants. World Health Organization.

[2] E. Athanassiadou, S.Tsiantzi, C.Markessini (2009) Producing Panels with Formaldehyde Emission at Wood Levels. https://www.researchgate. net/ publication/242310214 Producing Panels with For maldehyde Emission at Wood Levels

[3] J.Miljković, M.Popović (1999) Problem formaldehida u drvnim proizvodima posle dvadesetogodišnjih istraživanja, Drvarski glasnik, 31-32, 35-40.

[4] E.Athanassiadou (2008) Bio Resins for the Production of Composite Wood Panels. 1st Workshop 4F CROPS, Bologna.

[5] M.Irle, M.C.Barbu (2010) Wood-based panels technology. Poglavlje u: H.Thoemen, M.Irle, M.Šernek (eds.) Wood-Based Panels: An Introduction for Specialists (Brunel University Press)

[6] M.Dunky (1998). Urea-formaldehyde (UF) adhesive resins for wood, International Journal of Adhesion and Adhesives, 18, 95-107.

[7] A.R.Hawthorne, T.G.Matthews (1987) Models for estimating organic emissions from building materials: Formaldehyde example, Atmospheric Environment. 21(2), 419-424.

[8] B.Meyer, K.Hermanns (1986) Formaldehyde Release from Wood Products: An Overview. ACS Symposium Series, American Chemical Society, Washington, DC, 1986.

[9] I.Andersen, R.Lundquist, L.Mohave (1975) Indoor air pollution due to chipboard used as a construction material, Atmospheric Environment, 9, 1121-1127.

[10] E.Myers (1985) The effects of temperature and humidity on formaldehyde emission from UFbonded boards: A literature critique, Forest Products Journal, 35, 20-31.

[11] C.C.Lin, K.P.Yu, P.Zhao, G.W.M.Lee (2009) Evaluation of impact factors on VOC emissions and concentrations from wooden flooring based on chamber tests, Build. Environ., 44, 525-533.

[12] C.R.Frihart, J.M.Wescott, T.L.Chaffee, K.M.Gonner (2012) Formaldehyde Emissions from Urea 
Formaldehyde- and No-Added FormaldehydeBonded Particleboard as Influenced by Temperature and Relative Humidity, Forest Products Journal, 62(7/8), 551-558.

[13] EN 120 (1991) Wood based panels - Determination of formaldehyde content - Extraction method called the perforator method.
[14] Annon. (2016) Commission Decision (EU) $2016 / 1332$ of 28 July 2016 establishing the ecological criteria for the award of the EU Ecolabel for furniture. L 210/101.

[15] RAL-UZ 38 (2013) Basic Criteria for Award of the Environmental Label Low-Emission Furniture and Slatted Frames made of Wood and Wood-Based Materials, RAL gGmbH, Germany.

\section{IZVOD}

\section{KVALITET PLOČA IVERICA NA TRŽIŠTU SRBIJE U POGLEDU EMISIJE FORMALDEHIDA}

$U$ ovom radu istražen je trend kretanja emisije formaldehida iz ploča iverica uvezenih na tržište Srbije. Uzorkovanje i ispitivanje ploča iverica obavljeno je u dva vremenski odvojena perioda. Prvi period ispitivanja odvijao se tokom 2011. godine, a drugi tokom 2015-2016. godine. U oba ova perioda, uzorkovane su sirove ploče iverice, poreklom od tri različita proizvođača. Perforator metoda (EN 120) korišćena je za ispitivanje sadržaja formaldehida u uzorcima ploča. Rezultati pomenutih ispitivanja pokazali su da velika većina uzoraka pripada E1 klasi ploča iverica. Pored toga, oko 19 \% ploča iverica uzorkovanih u 2011. godini i oko 31 \% ploča uzorkovanih tokom perioda 2015-2016. godine imali su sadržaj formaldehida ispod 50 \% od zahteva za E1 klasom.

Ključne reči: ploča iverica, formaldehid, emisiona klasa, perforator.

Naučni rad

Rad primljen: 28. 06. 2018.

Rad prihvaćen: 17. 07. 2018.

Rad je dostupan na sajtu: www.idk.org.rs/casopis

(C) 2018 Authors. Published by Engineering Society for Corrosion. This article is an open access article distributed under the terms and conditions of the Creative Commons Attribution 4.0 International license (https://creativecommons.org/licenses/by/4.0/) 